\title{
Research on Technical Ceramics and their Industrial Application: Preparation Techniques and Properties of Transparent AlON Ceramics
}

\author{
Csaba BALÁZSI, Mónika FURKÓ, Fruzsina SZIRA, Katalin BALÁZSI \\ Thin Film Physics Department, Institute forTechnical Physics and Materials Science, Research Centre for \\ Natural Sciences, Hungarian Academy of Sciences, Budapest, Hungary, balazsi.csaba@energia.mta.hu
}

\begin{abstract}
Aluminium oxynitride (AlON) has a unique thermal and chemical stability that makes it the perfect candidate for a wide range of applications. This article provides a brief description and comparison of the most common AlON preparation methods along with their advantages and disadvantages. Although there has been extensive research on the material, especially more recently because of increased commercial interest, extensive systematic powder synthesis and processing studies have not been carried out to determine alternate, more cost efficient routes to fully dense transparent bodies. Further optimization of reaction sintering and transient liquid phase sintering could be important processing routes.
\end{abstract}

Keywords: AlON, transparent ceramics, Hot Isostatic Pressing (HIP), Spark Plasma Sintering (SPS).

\section{Introduction}

The discovery of aluminium oxynitride goes back to the 1970s, when researchers in Japan, the United States and France found that additions of nitrogen into aluminium oxide resulted in new spinel-like phases. This translucent aluminium oxynitride spinel ceramic was named AlON, a unique material exhibiting many important properties which make it useful in many applications and others yet to be determined. Currently commercially available AlON materials exhibit average grain sizes in the order of 150-200 $\mu \mathrm{m}$; however, development of new methods to control the grain size, especially at the nano-scale could create materials with improved properties. Because of its high hardness, there are still significant cost issues associated with final machining and polishing, especially for large bodies [1].

The individual properties of the AlON material lie in its unique crystal structure. Generally, it can be said that substitution of nitrogen for oxygen in $\mathrm{Al}_{2} \mathrm{O}_{3}$ or, conversely, substitution of oxygen into AIN stabilizes new phases with significantly different crystal structures and symmetry (space group): $\alpha-\mathrm{Al}_{2} \mathrm{O}_{3}, \mathrm{AION}$ and AIN rhombohedral, cubic, and hexagonal, respectively. AlON, having the cubic spinel structure, can be thought of as nitrogen stabilized cubic aluminium oxide. It has many properties comparable to $\mathrm{a}-\mathrm{Al}_{2} \mathrm{O}_{3}$, but because of its cubic crystal structure, fully dense, polycrystalline bodies can be completely transparent if processed properly [2]. Other properties, like dielectric loss tangent, can be extremely low because of the lack of thermal expansion-induced residual strain at grain boundaries. AlN is an intriguing material because its theoretical thermal conductivity at room temperature is extremely high for a dielectric material and comparable to, or higher than many metals [3].

\section{Overview of preparation techniques}

Over theyears several different processing routes have been used to produce fully dense, transparent polycrystalline AlON ceramics [2-14]. Their main parameters are summarized in Table 1. McCauley [2] used reaction sintering of $\mathrm{Al}_{2} \mathrm{O}_{3}-\mathrm{AlN}$ mixtures. The reaction sintering technique has also been used by others $[15,16]$. ]. Generally, the pressureless sintering, hot pressing and hot isostatic pressing (HIP) techniques have used AlON 
Table 1. Summary and characteristics of AlON techniques

\begin{tabular}{|c|c|c|c|c|}
\hline Method & & Advantages & Disadvantages & Ref. \\
\hline $\begin{array}{l}\text { Pressureless } \\
\text { sintering }\end{array}$ & $\begin{array}{l}\text { Sintering that is perfor- } \\
\text { med using only tempe- } \\
\text { rature. }\end{array}$ & $\begin{array}{l}\text { - Production procedure is } \\
\text { simple } \\
\text { - Cost effective }\end{array}$ & $\begin{array}{l}\text { - Higher temperature is } \\
\text { needed than in hot pressi- } \\
\text { ng techniques }\end{array}$ & [4] \\
\hline $\begin{array}{l}\text { Hot pressing } \\
\text { (HP) }\end{array}$ & $\begin{array}{l}\text { Combination of uniaxial } \\
\text { pressure and tempera- } \\
\text { ture. }\end{array}$ & $\begin{array}{l}\text { - Production procedure is } \\
\text { simple } \\
\text { - Sintering density is high, } \\
\text { - The quality of end products } \\
\text { is good with high density }\end{array}$ & $\begin{array}{l}\text { - Expensive (high pressure, } \\
\text { high temperature) } \\
\text { - Only simple shapes can } \\
\text { be created }\end{array}$ & [5] \\
\hline $\begin{array}{l}\text { Hot isostatic } \\
\text { pressing (HIP) }\end{array}$ & $\begin{array}{l}\text { Simultaneous app- } \\
\text { lication of heat and } \\
\text { hydrostatic pressure to } \\
\text { compact and densify a } \\
\text { powder. }\end{array}$ & $\begin{array}{l}\text { - High density can be achie- } \\
\text { ved } \\
\text { - Densification can be } \\
\text { com-pleted in shorter times } \\
\text { and at lower temperatures } \\
\text { than conventional sintering } \\
\text { - Products with complex geo- } \\
\text { metry can be produced } \\
\text { - The quality of end prod-ucts } \\
\text { is good }\end{array}$ & $\begin{array}{l}\text { - Expensive (high pressure } \\
\text { and high temperature, } \\
\text { ex-pendable tools) } \\
\text { - The processes are comp- } \\
\text { lex } \\
\text { - Small production quantit- } \\
\text { ies }\end{array}$ & {$[6,7]$} \\
\hline $\begin{array}{l}\text { Spark plasma } \\
\text { sintering (SPS) }\end{array}$ & $\begin{array}{l}\text { The process applies } \\
\text { pressure and (pulsed) } \\
\text { current flow through the } \\
\text { sample at the same time } \\
\text { in vacuum }\end{array}$ & $\begin{array}{l}\text { - Fast heating, } \\
\text { - Effective for densification of } \\
\text { a wide variety of mate-rials } \\
\text { - Densification occurs at } \\
\text { lower temperature and is } \\
\text { completed more rapidly } \\
\text { than in other methods }\end{array}$ & $\begin{array}{l}\text { - Complicated setup and } \\
\text { limited sample shape } \\
\text { - Hard to operate, } \\
\text { - Expensive pulsed DC ge- } \\
\text { nerator is required }\end{array}$ & [8-10] \\
\hline $\begin{array}{l}\text { Carbothermal } \\
\text { synthesis (CT) }\end{array}$ & $\begin{array}{l}\text { The technology uses } \\
\text { graphite furnace at } \\
\text { different temperatures } \\
\left(1700-1860^{\circ} \mathrm{C}\right) \\
\text { and pressures }(0.1-10 \\
\mathrm{MPa}) \text { in } \mathrm{N}_{2} \text { atmosphere }\end{array}$ & $\begin{array}{l}\text { - Simple } \\
\text { - Cost effective } \\
\text { - Possible to obtain very fine } \\
\text { powder with a low metal } \\
\text { impurity }\end{array}$ & $\begin{array}{l}\text { - Higher tempera-tures } \\
\text { and longer reaction times } \\
\text { needed } \\
\text { - Thermal decomposition } \\
\text { process is too complex } \\
\text { - Carbon impurities }\end{array}$ & [13] \\
\hline Direct nitriding & $\begin{array}{l}\text { Thermochemical surface } \\
\text { treatment process, Al- } \\
\mathrm{Al}_{2} \mathrm{O}_{3} \text { starting mixtures }\end{array}$ & $\begin{array}{l}\text { - Simple } \\
\text { - Cost effective }\end{array}$ & $\begin{array}{l}\text { - Lower transparen-cy } \\
\text { - Lower quality of product }\end{array}$ & [14] \\
\hline
\end{tabular}

powders to produce pore free, fully dense AlON ceramics. AlON powders can be synthesized by simple reaction of $\mathrm{Al}_{2} \mathrm{O}_{3}$ and $\mathrm{AlN}$, carbothermal reduction of $\mathrm{Al}_{2} \mathrm{O}_{3}$. Significant variations in hardness, flexure strength and fracture toughness were observed. The friction, wear resistance and other mechanical properties of the $\mathrm{Al}_{2} \mathrm{O}_{3}-\mathrm{AlON}$ family of materials has also been systematically studied [17, 18]. High sintering temperature and long sintering time are two major problems in the above methods. Therefore, it is critical to lower the sintering temperature and reduce the sintering time without reducing material performance.

\section{State of the art in development of AlON}

The most commonly used and promising techniques in industry are the HP, HIP and SPS. Shan et al. [9] used spark plasma sintering (SPS) in their research work with $\mathrm{Al}_{2} \mathrm{O}_{3}$ and AlN powder mixtures to produce AlON ceramics. The SPS was performed at temperatures between 1400 and $1650{ }^{\circ} \mathrm{C}$ for $15-45 \mathrm{~min}$. at $40 \mathrm{MPa}$ under $\mathrm{N}_{2}$ gas flow. They found that AlON phase formation was initiated in the samples sintered above $1430{ }^{\circ} \mathrm{C}$. The complete transformation of the initial phases $\left(\mathrm{Al}_{2} \mathrm{O}_{3}\right.$ and $\left.\mathrm{AlN}\right)$ into $\mathrm{AlON}$ was observed in the 
samples that were spark plasma sintered at 1650 ${ }^{\circ} \mathrm{C}$ for $30 \mathrm{~min}$ at $40 \mathrm{MPa}$. A high spark plasma sintering temperature together with a low heating rate yielded a greater amount of AlON formation at a constant process time.

Increasing the spark plasma sintering temperature from 1430 to $1650^{\circ} \mathrm{C}$ significantly increased the degree of AlON phase formation. Although most of the studies on AlON formation by reaction sintering of $\mathrm{Al}_{2} \mathrm{O}_{3}$ and AlN powders have indicated that sintering temperatures above $1650^{\circ} \mathrm{C}$ and a sintering duration longer than $2 \mathrm{~h}$ require volume diffusion to obtain pure, dense AlON ceramics, spark plasma sintering produced pure AlON ceramics above $98.5 \%$ of the theoretical density by sintering at $1650{ }^{\circ} \mathrm{C}$ for $30 \mathrm{~min}$ with a $50^{\circ} \mathrm{C} /$ min. heating rate [9]. The AlON ceramics can also be prepared by SPS at low temperature $\left(<1650^{\circ} \mathrm{C}\right)$ and short sintering time (5-15 min.), however, the hardness and the relative density became a little higher and a little grain growth was found with increasing soaking time. Although relative density increased and pores gradually disappeared, the grain size of AlON also grew with the holding time. Larger grains led to a decrease in the flexural strength and elasticity modulus. Fully dense AlON ceramics cannot be fabricated by SPS without sintering additives whether under nitrogen or vacuum. Moreover, AlON ceramics possessed better properties fabricated under vacuum than under $\mathrm{N}_{2}$ atmosphere [10, 11]. By using different additives, the residual porosity of transparent AlON can be reduced to a minimum. Although sintering additives can reduce the sintering temperature and increase the density of AlON ceramics, it is important to avoid generating a second phase that would reduce the transparency of AlON ceramics [12].

Chen et al. [7] ] prepared highly transparent AlON composite ceramics by hot isostatic pressing (HIP) of the sintered bodies composed of fine grains $(\sim 20 \mu \mathrm{m})$. They also found that sintering additives play a huge role in the porosity and pore positions of the sintered AlON bodies, which can determine the final pore elimination during HIP sintering. They claimed that compared to single $\mathrm{Y}_{2} \mathrm{O}_{3}$ or $\mathrm{La}_{2} \mathrm{O}_{3}$ additive, the co-doping of $\mathrm{Y}_{2} \mathrm{O}_{3} / \mathrm{La}_{2} \mathrm{O}_{3}$ additive is more effective in preparing a sintered AlON body with small intergranular pores and lower porosity. The developed transparent AlON ceramic had an in-line transmittance as high as $85.0 \%$ at $1100 \mathrm{~nm}$ with low concentration of additives. The transmittance was sensitive to the microstructure of presintered AlON bodies.
Except for the strong driving force enabled by HIP method, the small amount of $\mathrm{Y}_{2} \mathrm{O}_{3} / \mathrm{La}_{2} \mathrm{O}_{3}$ additives was effective in fabricating pre-sintered AlON bodies with small intergranular pores and lower porosity. Such AlON bodies were then easy to densify during HIP sintering and were significant to give high transparency. The necessary additives for the HIP-ed AlON ceramics ( $4.2 \mathrm{~mm}$ thick) to achieve full density were $0.08 \% \mathrm{Y}_{2} \mathrm{O}_{3}$ and $0.02 \%$ $\mathrm{La}_{2} \mathrm{O}_{3}$, much lower than previously reported data in pressureless sintered samples $\left(0.12 \% \mathrm{Y}_{2} \mathrm{O}_{3}\right.$ and $0.09 \% \mathrm{La}_{2} \mathrm{O}_{3}$ ).

The densities and transparency characteristics of AlON prepared by different techniques are compared in Figure 1. It can be seen that the relative densities of AlON prepared by different methods are all close to $100 \%$, which demonstrates their effectiveness in obtaining pure and dense ceramics. According to the thorough literature survey, the transparency of AlON ceramics produced by different methods shows significant differences. The lowest transparency was measured in the case of the CT method (65\%), while in the other methods the transparency values of all samples were above $75 \%$. The highest transparency was measured in the case of SPS technology (79.2 $22.4 \%)$.

Nowadays, there are several companies that produce AlON ceramics for different use.

The pathway of incident and reflected light is illustrated schematically in Figure 2.

AThe interference between the incident light and the polycrystalline ceramics can be understood by further examination of the mechanism

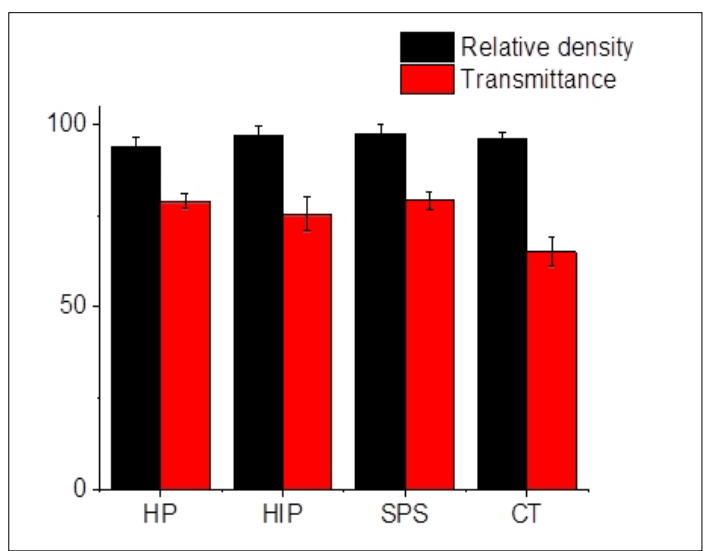

Figure 1. Relative densities and transmittance percentages (in visible wavelenght range) of AlON samples prepared by different techniques. The relative density was calculated using a theoretical density of $3,71 \mathrm{~g} / \mathrm{cm}^{3}$ 
of refraction and reflection of light. In general, distortion often occurs close to the surface of a ceramic and at grain boundaries. Local distortion and strained layers resulting from surface processing give rise to localized changes of refractive index, causing light to be scattered and affecting the optical transmittance (Figure 3).

In Figure 4 és 5 we demonstrate the applied characteristic temperature ranges of investigated preparation techniques as well as the hardness values of the yielded transparent ceramics. It can be seen that the hardest AlON ceramic can be achieved by SPS method at the lowest preparation temperature. AlON can serve as a model material for polycrystalline ceramics and, because of its transparency, real time diagnostic observations can be easily carried out in many mechanical tests. Other possible applications of AlON materials include transparent armour, EM domes and windows, military aircraft and missile domes, IR windows, hyper-hemispherical domes, laser windows, military aircraft lenses, semiconductor processing applications, and scanner windows (point of sale (POS) windows).

Figure 6 shows the flexural strength of different AlON samples. It is visible that the highest strength belongs to the AlON ceramic prepared by SPS method, while the differences in the values of flexural strength in the cases of ceramics prepared by HP and HIP methods are insignificant. The sample prepared by CT method has the lowest strength.

The other important mechanical property for possible industrial application is fracture toughness. The changes of this parameter in samples prepared with different methods are presented in Figure 7.

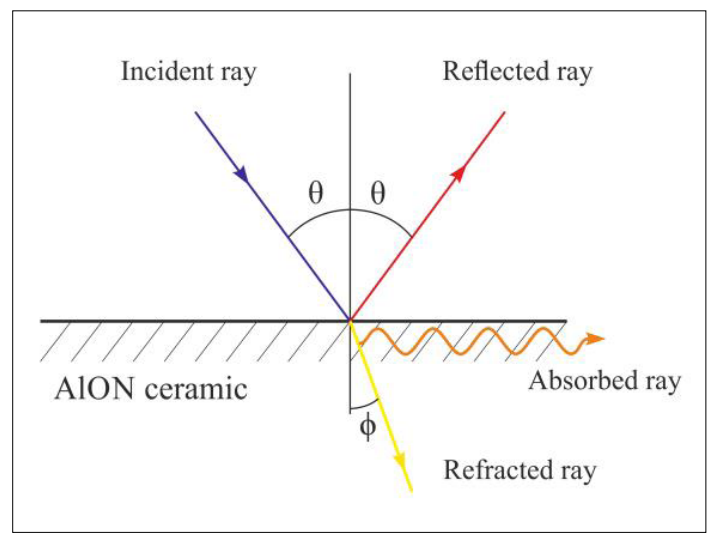

Figure 2. Schematic illustration of the reflection and re-fraction mechanism of light

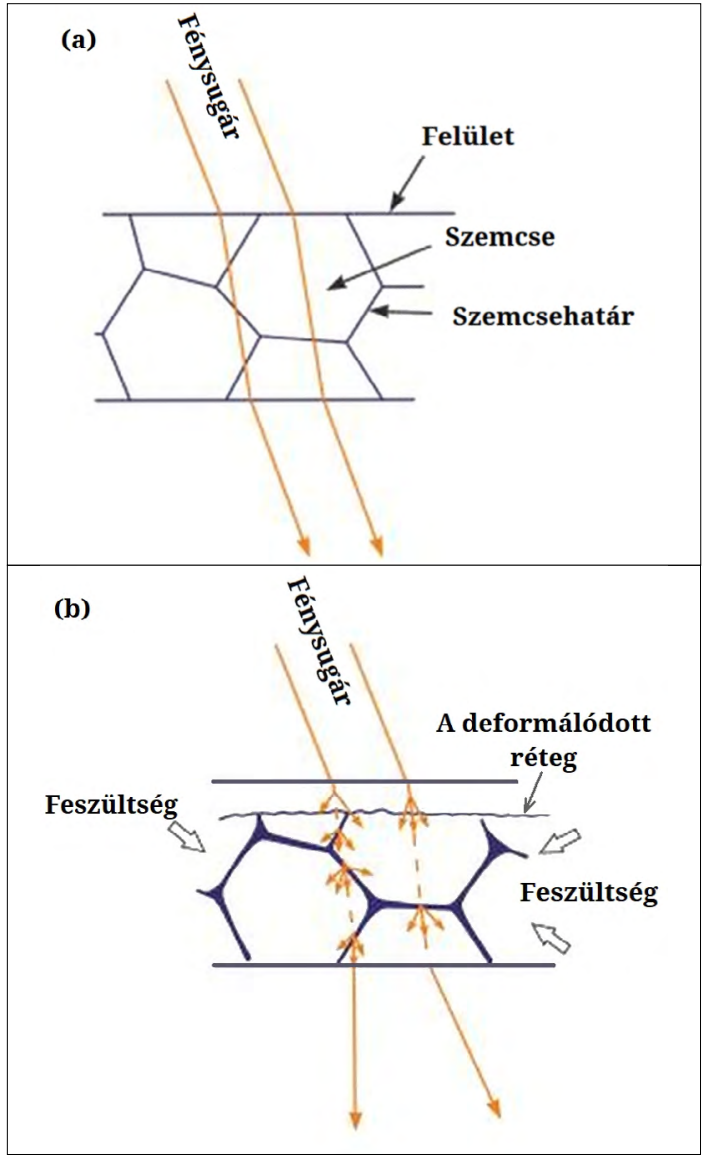

Figure 3. Interaction scheme between the light and the isotropic polycrystalline ceramics. (a) Ideal homogenous polycrystal with theoretical density. Light is not scattered about grain boundaries. (b) Polycrystal with internal strain and external stress. Light is scattered in the inhomogenous region

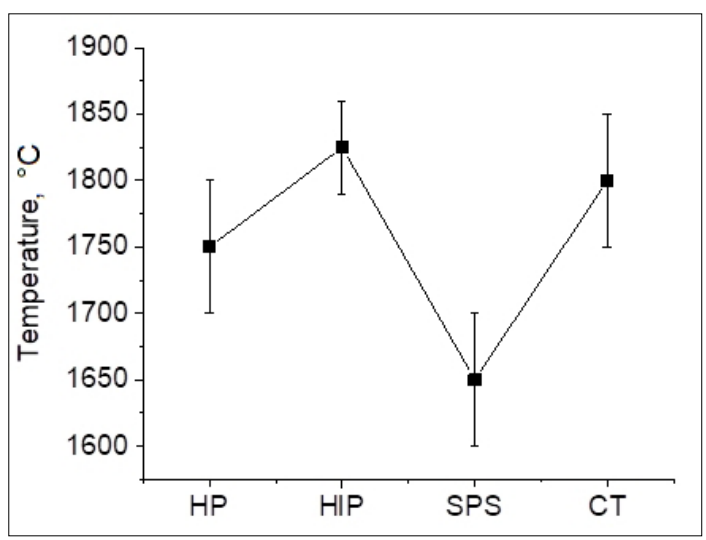

Figure 4. The applied temperature ranges in different techniques 
In this case, similarly, the sample prepared by SPS has the highest fracture toughness, while the lowest toughness value belongs to samples prepared by CT method.

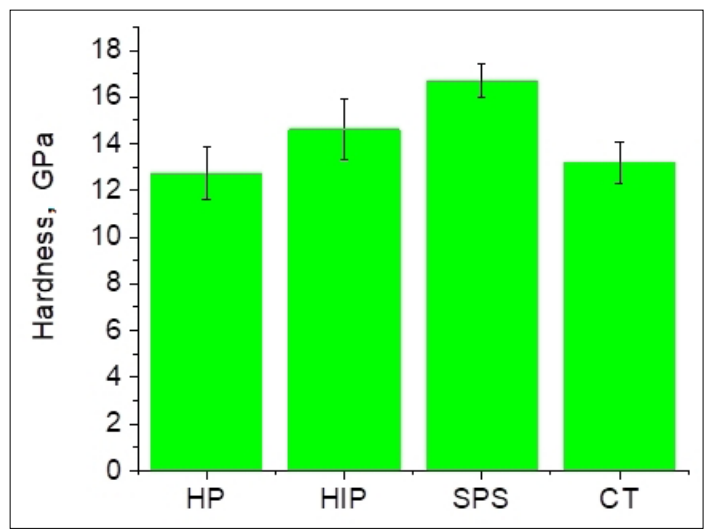

Figure 5. The hardness values of AlON samples prepared by different techniques

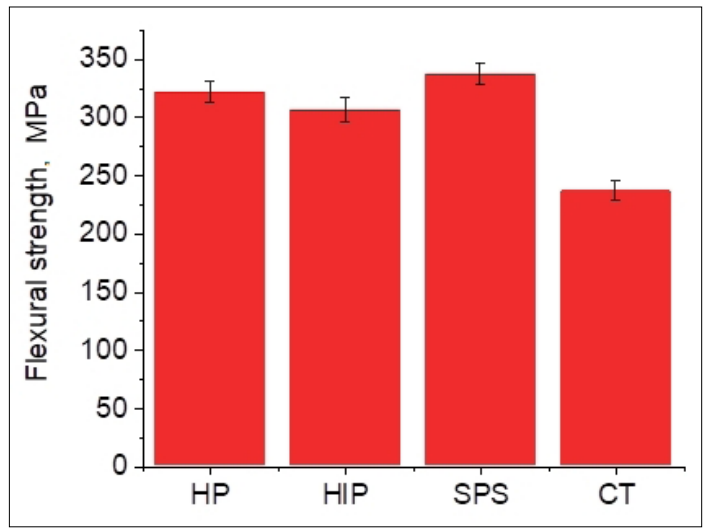

Figure 6. Flexural strength values of AlON samples prepared by different techniques

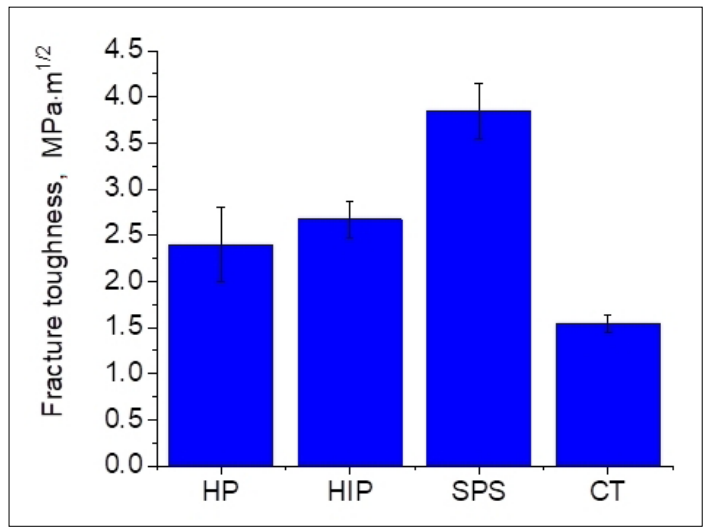

Figure 7. Fracture toughness of AlON samples prepared by different techniques
Zhao et al. [5] studied the effect of different additives, such as SiC and ZrN nano-particles on the mechanical properties of AlON ceramic. Their work revealed that the nano-sized additives positioned at grain boundaries of micro-sized AlON particles and the presence of $\mathrm{SiC}$ and $\mathrm{ZrN}$ nano-particles resulted in the reduction of both porosity and grain size, and a change of fracture mode from intergranular cracking in AlON to intragranular cracking in composites. With presence of small amount (5-8 \%) of additive particles, the relative density, microhardness, flexural strength and fracture toughness increased owing to the hindered crack propagation processes. Li et al. [11] prepared transparent AlON ceramic by SPS method. Their results showed that fully dense AlON ceramics cannot be fabricated by SPS without sintering additives whether under nitrogen or vacuum. There was even a contradiction between transparency and mechanical properties of AlON ceramics with increased holding time, heating rate and sintering temperature. Although sintering additives can reduce spark plasma sintering temperature and increase the density of AlON ceramics, generation of a second phase that would reduce the transparency of AlON ceramics should be avoided.

\section{Conclusions}

According to the thoroughly studied literature data and the state of the art on AlON preparation we can conclude that the currently available and used techniques are still all expensive, as well as being energy and time consuming. High temperatures above $1600-1900{ }^{\circ} \mathrm{C}$ are needed for a long time to achieve appropriate phase and densification. We intend to develop an eco-friendly preparation method of AlON in which we develop a novel way to reduce the temperature and/or time thus requiring lower energy (technique, temperature and so on). Moreover, we are planning to recycle and utilize the industrial by-products or aluminium waste (such as aluminium cans) as $\mathrm{Al}$ source.

\section{Acknowledgement}

The authors acknowledge the support from „Eco-friendly AlON Processing” NNE129976 NKFIH project.

\section{References}

[1] McCauley J. W., Patel P., Chen M., Gilde G., Strassburger E., Paliwal B., Ramesh K. T., Dandekar D. P.: AlON: A brief history of its emergence and evolution. Journal of the European Ceramic Society, 
29/2. (2009) 223-236.

https://doi.org/10.1016/j.jeurceramsoc.2008.03.046

[2] McCauley J. W., Corbin N. D.: Phase Relations and Reaction Sintering of Transparent Cubic AIurninum Oxynitride Spine1 (AION). Journal of the American Ceramic Society, 62/9-10. (1979) 476-479.

https://doi.org/10.1111/j.1151-2916.1979. tb19109.x

[3] McCauley J. W.: Structure and Properties of Aluminum Nitride and AlON Ceramics. Army Research Laboratory Aberdeen Proving Ground, (2002) MD 210053069.

https://doi.org/10.1016/B0-08-043152-6/00028-0

[4] Shan Y., Zhang Z., Sun X., Xu J., Qin Q., Li J.: Fast densification mechanism of bimodal powder during pressureless sintering of transparent AlON ceramics. Journal of the European Ceramic Society, 36/3. (2016) 671-678.

h t tps://doi.org/10.1016/j.jeurceramsoc.2015.10.026

[5] Zhang N., Liang B., Wang X. Y., Kan H. M., Zhua $\mathrm{K}$. W., Zhao X. J.: The pressureless sintering and mechanical properties of AlON ceramic. Materials Science and Engineering A, 528/19-20. (2011) 6259-6262.

https://doi.org/10.1016/j.msea.2011.04.072

[6] Jiang N., Liu Q., Xie T., Ma P., Kou H., Pan Y., Li J.: Fabrication of highly transparent AlON ceramics by hot isostatic pressing post-treatment. Journal of the European Ceramic Society, 37/13. (2017) 4213-4216.

https://doi.org/10.1016/j.jeurceramsoc.2017.04.028

[7] Chen F., Zhang F., Wang J., Zhang H., Tian R., Zhang Z., Wang S.: Hot isostatic pressing of transparent AlON ceramics with $\mathrm{Y}_{2} \mathrm{O}_{3} / \mathrm{La}_{2} \mathrm{O}_{3}$ additives. Journal of Alloys and Compounds, 650. (2015) 753-757.

https://doi.org/10.1016/j.jallcom.2015.08.028

[8] Xue J. M., Liu Q., Xiu T., Ma L., Fang M., Gui L.: HotPressed Translucent Aluminum Oxynitride (AlON) Ceramics. Key Engineering Materials, 368-372. (2008) 450-452.

https://doi.org/10.4028/www.scientific.net/ KEM.368-372.450

[9] Shan Y, Zhang Z., Sun X., Xu J., Qin Q., Li J.: Further experimental investigation on fast densification mechanism of bimodal powder during pressureless sintering of transparent AlON ceramics. Ce- ramics International, 43/11. (2017) 8195-8201.

https://doi.org/10.1016/j.ceramint.2017.03.146

[10] Sahin F. C., Kanbur H. E., Apak B.: Preparation of AlON ceramics via reactive spark plasma sintering. Journal of the European Ceramic Society, 32/4. (2012) 925-929.

https://doi.org/10.1016/j.jeurceramsoc.2011.10.043

[11] Li X., Huang J., Luo J.: Progress and Challenges in the Synthesis of AlON Ceramics by Spark Plasma Sintering. Transactions of the Indian Ceramic Society, 76/1. (2017). 14-20.

https://doi.org/10.1080/0371750X.2016.1257956

[12] Zientara D., Bucko M. M., Lis J.: Dielectric properties of aluminium nitride- $\gamma$-AlO materials. Journal of the European Ceramic Society, 27/13-15. (2007) 4051-4054.

https://doi.org/10.1016/j.jeurceramsoc.2007.02.093

[13] Zheng J., Forslund B.: Carbothermal Synthesis of Aluminium Oxynitride (ALON) Powder: Influence of Starting Materials and Synthesis Parameters. Journal of the European Ceramic Society, 15/11. (1995) 1087-1100. https://doi.org/10.1016/0955-2219(95)00078-9

[14] Su M., Zhou Y., Wang K., Yang Z., Cao Y., Hong M.: Highly transparent AlON sintered from powder synthesized by direct nitridation. Journal of the European Ceramic Society, 35. (2015) 1173-1178.

[15] Kim Y. W., Park B. H., Park H. C., Lee Y. B., Oh K. D., Riley F.: Sintering, microstructure and mechanical properties of AlON-AlN particulate composites. British Ceramics Transactions, 97/3. (1998) 97-104.

[16] Kim Y. W., Park H. C., Lee Y. B., Oh K. D., Stevens R.: Reaction sintering and microstructural development in the system $\mathrm{Al}_{2} \mathrm{O}_{3}-\mathrm{AlN}$. Journal of the European Ceramic Society, 21/13. (2001) 23832391.

https://doi.org/10.1016/S0955-2219(01)00200-X

[17] Trabelsi R., Treheux D., Goeuriot-Launay D., Goeuriot P., Thevenot F., Orange G. et al.: Friction, wear resistance and mechanical properties of an alumina- $\gamma$-aluminum oxynitride composite (ALUMINALON). In: High Tech Ceramics. (ed. P. Vincenzini) Elsevier Sci. Pub., (1987) 2683-2695.

[18] Berriche Y., Vallayer J., Trabelsi R., Treheux D.: Severe wear mechanisms in $\mathrm{Al}_{2} \mathrm{O}_{3}-\mathrm{AlON}$ ceramic composites. Journal of the European Ceramic Society, 20/9. (2000) 1311-1318.

https://doi.org/10.1016/S0955-2219(99)00294-0 